\title{
ПРОБЛЕМНО-ОРІЄНТОВАНА ОСВІТА
}

\author{
О. В. Поканевич, М. М. Матяш, Л. І. Худенко \\ ПВНЗ “Київський медичний університет УАНМ”
}

PROBLEM-ORIENTED EDUCATION

\author{
O. V. Pokanevych, M. M. Matyash, L. I. Khudenko \\ PHEI "Kyiv Medical University of UAFM"
}

\begin{abstract}
У статті, з метою ефективної інтеграції в Європейський освітній простір, окреслені проблеми сучасної освіти в Україні. Визначено, що ефективне професійне формування студента медичного університету можливе з врахуванням характерологічних, етнокультуральних особливостей особистості та є невідривним від розвитку країни.
\end{abstract}

The article, for the purpose of effective integration into the European educational space, adduces the problems of modern education in Ukraine. It is noted that the effective professional formation of a student of Medical University is possible into account the characterogical, etnocultural features of personality and is a part of the development of the country.

Учітесь, читайте, і чужому научайтесь, й свого не иурайтесь...

Т. Шевченко

Вступ. У період структурних змін сучасного світу, та встановлення єдиного освітнього простору в європейських країнах, відбувається формування й нашої Української державності. Процеси європейської інтеграції проходять у різних сферах життя українського суспільства. Відбувається формування інститутів громадянського суспільства, які представляють інтереси людей і створюють зв’язки для поєднання їх $з$ державою. Побудова нового українського громадянського суспільства вимагає необхідності формування якісно інших спеціалістів, з орієнтацією на особистість, на її духовність, інтелектуальність, на пошук, спільних 3 європейськими, цінностей та впровадження їх у медичній освіті.

На жаль, висока доступність вищої освіти, переважно економіко-правового спрямування, особливості ментальності (наявність диплома - престижно) при відсутності умов для підвищення попиту на даний контингент спеціалістів, склався своєрідний дисбаланс між ринковим запитом та пропозиціями навчальних закладів.

Основна частина. Імплементація нового Закону України “Про вищу освіту” поставила перед вищими навчальними закладами складні проблеми та викликала серйозні дискусії в суспільстві. На сьо-

(C) О. В. Поканевич, М. М. Матяш, Л. І. Худенко годні університети знаходяться в складній ситуації: з одного боку, велика академічна самостійність, з іншого - не менша відповідальність; досить довге в часі введення окремих положень закону та наявність великої кількості підзаконних актів. Також необхідно враховувати особливості ментальності керівного складу більшості університетів у вигляді очікування чітких вказівок з боку Міністерства освіти та науки.

В порівнянні з західними університетами, де освіта на молодших курсах у вузі для всіх $€$ обов’язково гуманітарно направленою, при переході до вивчення спеціальних дисциплін, наприклад на медичному курсі, при більш детальному ознайомленні з фаховою специфікою відбувається природний відсів студентів (до 10 \%) на кожному факультеті. Таким чином із прийнятих на навчання 100 чол. на I курс отримують диплом лікаря близько 30 чол. Тоді як в нашому суспільстві, де відбувається боротьба за кожного студента, із прийнятих на навчання 100 чол. на І курс, отримують диплом лікаря 102 - 105 чол. за рахунок переведених студентів 3 інших вузів. За цим стоїть економічний фактор у приватному вузі та залежність від бюджетного фінансування і в державних вузах у тому числі, яке теж залежить від кількості студентів.

Саме освіта впливає на стан економіки та реалізацію ефективних соціальних процесів у державі - як 
кінцевий результат на благополуччя членів суспільства, за виразом відомого психолога Р. М. Сміта, “навчання включає в себе зміни в людині, яка навчається”. Згадуючи досвід системи жорсткого планування освіти в радянські часи, яка була малоефективною, малосприятливою для індивідуального розвитку людини, через свій жорсткий командно-адміністративний стиль - при пануванні тоталітарної системи та притаманних їй цінностей. Недоліки її збереглись і в пострадянському суспільно-економічному складі, де в навчальній системі був акцент на колективну індукцію, то в даний час згідно з досвідом європейських фахівців у галузі освіти визначено, що головним завданням для забезпечення високої якості освіти є перехід на клієнтоцентрований - студентоцентрований принцип викладання. Коли на першому місці знаходяться не методи та засоби викладання предметів, не колектив у цілому, а переважає акцент на особистості кожного конкретного учасника навчального процесу. Особливістю такого типу освітньої моделі є також активна позиція студента; малі групи; збільшення частки самостійного навчання; використання сучасних інформаційних технологій; збільшення ролі викладача - як моделі.

Самостійність, відповідальність за набуття професійної компетентності - риса характерна для студентів сучасних вузів. Реформа вищої освіти в Україні має на меті позбутися радянських традицій, заснованих на диктаті, приниженні людської гідності, пасивності, знеціненні особистості. Результатом цієї освітньої реформи повинна стати еволюція Homo sovetikus у Людину європейську, зміна колективної свідомості та цивілізаційні зміни в цілому.

Ефективність навчання визначається особистістю студента - особливостями характеру, темпераменту, інтелекту, адже формування особистості лікаря $є$ складним процесом й триває все життя. Роллю викладача в університеті є стимулювання прагнення до самоактуалізації студента - це й виховання здібності до адекватної самооцінки та до гармонійного світосприйняття. За А. Адлером, найважливішим мотивом особистісного розвитку $\epsilon$ прагнення до успіху й самовдосконалення, та конструктивний соціальний інтерес, що сприяє успішній взаємодії з іншими людьми.

Положення Закону України “Про вищу освіту”, щодо зменшення аудиторного навантаження студентів, має на меті сприяння більшій їх самостійності. Ситуація, що склалася в навчальному процесі минулої зими, у вигляді ущільнення педагогічного навантаження, що мала під собою об’єктивні причини, найімовірніше не повториться в майбутньому. І страхи студентів про збільшення кількості академічних годин на день - безпідставні. Відомо, що підготовка лікарів потребує більшого часу на заняття в лабораторіях та практичну підготовку. Тому частка аудиторного навчання повинна бути для них більшою, особливо на перших курсах.

Звернемо увагу на те, що особистісний успіх можливий лише у психологічно гармонійному суспільстві. Також кожна особистість, навіть позиціонуючи себе громадянином світу, що найцінніше $є$ носієм унікальної культури - має своє етнічне коріння. Значною є роль етнічної ідентичності в системі “Я” особистості, тому важливо для свого розвитку прийняття як факту, феномену етнічної самоідентифікації. Етнічна ж ідентичність та національна самобутність є підструктурою соціальної ідентичності, яка поряд 3 особистісною виступає частиною “Я-концепції”.

У більшості українських студентів наявні домінантні риси українського психотипу, зі значним спектром типологічних національних рис. Унікальні етнопсихологічні та етнокультурні складові ментальності - українська волелюбність, розуміння національної самобутності, неповторності та вибору співіснуваня та співпраці з іншими також самобутніми культурами, опосередковано впливають і на професійне самовизначення особистості й професійну самореалізацію. Тому підвищення якості освіти - отримання кращого спеціаліста на виході можливо тільки з урахуванням цих особливостей.

Висновки: 1. Положення Закону України “Про вищу освіту”, щодо зменшення аудиторного навантаження студентів, має на меті сприяння більшій їх самостійності - неприйнятне для медичного університету. В зв'язку з тим, що підготовка лікарів потребує більшого часу на заняття в лабораторіях та практичну підготовку - частка аудиторного навчання повинна бути більшою.

2. $€$ необхідність при наданні освітніх послуг і здійсненні професійної підготовки фахівців, які відповідають стандартам вищої медичної освіти та потребам держави і будуть задовольняти вимоги ринку праці.

3. Рекомендовано приділити увагу етнічній ідентичності українського суспільства, особливим етнокультуральним чинникам, які впливають на вибір шляхів для самовдосконалення та професійну самовизначеність особистості. 


\section{Список літератури}

1. Методологія і технологія визначення універсальних компетенцій випускників медичних та стоматологічних факультетів / [Ю.В.Думанський, Б. Б. Івнєв, М.Б.Первак та ін.]. - Донецьк, 2013. - 112 с.

2. Мотрук Р. В. Етнічна ідентичність як чинник професійного самовизначення особистості: досвід структурнодинамічного моделювання / Р. В. Мотрук // Теоретичні і прикладні проблеми психології. - 2013. - № 2 (31). C. $174-180$.
3. Омельченко Л. М. Соціальна ідентичність особистості в ситуації невизначеності / Л. М. Омельченко // Психологічні перспективи. Спеціальний випуск : Актуальні проблеми психології малих, середніх та великих груп. Т. 2 : Проблема цілісності суспільства, групи та особистості. - К. : Вид-во ІСПП НАПН України, 2012. - C. 117-124.

4. Титаренко Т. М. Особистісне самоконструювання: циклічно-поступальна динаміка / Т. М. Титаренко // Психологія і особистість. - 2013. - № 1 (3). - С. 85-95.

Отримано 18.06.15 